\title{
大動脈壁抽出物質に対する正常者と家族性高コレステロール 血症患者の末梢血単球の遊走能*
}

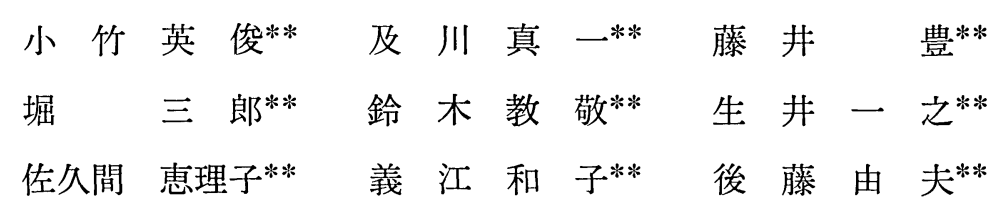

\section{I. はじめに}

血管壁に㧍ける泡沫細胞の起源として, マクロ ファージ $(\mathrm{M} \phi)$ が注目されているが, 泡沫化に先 立って, 未梢血巣球の動脈壁への付着, 内皮下一 の遊走・集簇が生ずると考えられる。したがって， このような単球の走化性を検討することは, 動脈 硬化初期病巣形成の機序解明注重要と思われる.

これまで, 単球汶対する走化作用は, 血小板由 来増殖因子 $(\mathrm{PDGF})^{1)}$, コラーゲン2), エラスチ ン3), カリクレイン4), プラスミノーゲン・アク チベーター4), フィブロネクチン5), トロンビン6) などに存在すると考えられ，また血管壁平滑筋細 胞7), 線維芽細胞 ${ }^{8)}$, 大血管内皮細胞 ${ }^{9}$, 単球由来 $\mathrm{M} \phi^{10)}$ など，このような走化誘発物質を分泌す ると考元られている。

今回, われわれはヒ卜胸部下行大動脈正常部 内・中膜よりの抽出物質に走化活性を認めたこと から, この物質を走化因子として, 正常者および 家族性高コレステロール血症 $(\mathrm{FH})$ 患者の末梢血 単球の走化性を比較検討した。

\section{II. 対象と方法}

年齢のほぼ合致した正常者 4 例, IIa 型 FH 3

* 1987 年 2 月, 日本動脈硬化学会 昭和 61 年度冬季 大会において発表

** 東北大学医学部第三内科

原稿受取日 : 1987 年 6 月 12 日

採用決定日：1987 年 9 月 8 日
例，および非家族性高脂血症例 IIa 型，IIb 型， IV 型各 1 例ずつを対象とした (Table 1).

早朝空腹時採血より得た血清を Havel ら ${ }^{11)}$ の 方法に準じて各リポ蛋白に分画し, 総コレステロ ール (TC), トリグリセリド (TG) を酵素法で測 定した.

同様に，ヘパリン加採血にて得た末梢血より， Ficoll-paque ${ }^{\circledR}$ を用いた比重分離法 ${ }^{12)} に て$ 単核細 胞を分離し，培盖フラスコへの付着細胞を $10 \%$ ウシ胎児血清加 RPMI 培地にて，48 時間培養し たものを末梢血単球として, 実験に供した。

大動脈壁抽出物質は, 当科剖検例より得た胸部 下行大動脈の肉眼的正常部位における内・中膜を Hoff らの方法 ${ }^{13)}$ に準じてホモジナイズし，1 $\mathrm{g}$ 湿 重量あたり $10 \mathrm{ml}$ の生食を用い水溶性画分を抽出 した.

単球の走化性の検討は, Horwitz ら ${ }^{14)}$ の Boyden 変法にて行った. 遊走因子として, 内膜・中膜よ りの抽出物質 $200 \mu l$ および生食 $200 \mu l$ を chemotaxis chamber の下室に入れ, $1 \times 10^{5}$ の単球を上 室に加えて, $37^{\circ} \mathrm{C}$ に 120 分間培養し chemotaxis membrane の下面に遊走した細胞数を数えた. 走 化能は, chemotactic index (C.I.) すなわち, 抽出 物質に対して遊走した細胞数を生食に対して遊走 した細胞数で除した值を用いて検討した。

大動脈壁抽出物質注対し, 単球が実際に遊走す るか否かの検討は checker board assay により行 った。すなわち chemotaxis chamber の上・下室 
動脈硬化 Vol.15 No.7 1987

Table 1 Subject

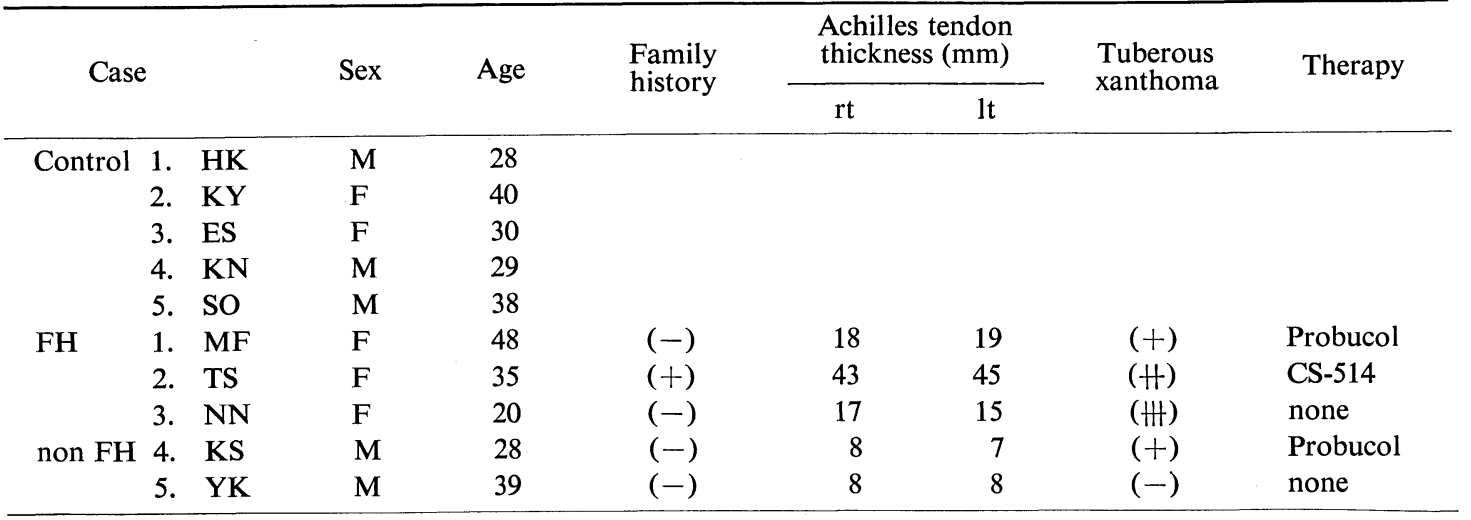

Table 2 Checker board assay for plasma monocyte migration

\begin{tabular}{ccccc}
\hline \multirow{2}{*}{$\begin{array}{c}\text { Addition of } \\
\text { aorta extract }\end{array}$} & & \multicolumn{3}{c}{ Superior chamber } \\
\cline { 2 - 5 } & & \multicolumn{1}{c}{0} & $100^{-1}$ & $10^{-1}$ \\
\hline Inferior & 0 & 1.0 & 0.1 & 0.0 \\
chamber & $100^{-1}$ & 4.1 & 1.4 & 0.1 \\
& $10^{-1}$ & 16.9 & 11.0 & 0.7 \\
& 1 & 53.7 & 20.4 & 8.4 \\
\hline
\end{tabular}

Table 3 Total cholesterol concentration $(\mathrm{mg} / \mathrm{d} l)$

\begin{tabular}{|c|c|c|c|c|c|c|c|}
\hline \multicolumn{2}{|c|}{ Case } & \multirow{2}{*}{$\begin{array}{c}\text { Serum } \\
134\end{array}$} & \multirow{2}{*}{$\frac{\text { VLDL }}{6}$} & \multirow{2}{*}{$\begin{array}{c}\text { IDL } \\
1\end{array}$} & \multirow{2}{*}{$\begin{array}{c}\text { LDL } \\
86\end{array}$} & \multirow{2}{*}{$\begin{array}{c}\mathrm{HDL}_{2} \\
26\end{array}$} & \multirow{2}{*}{$\begin{array}{c}\mathrm{HDL}_{3} \\
15\end{array}$} \\
\hline Control & 1. $\mathrm{HK}$ & & & & & & \\
\hline & 2. $\mathrm{KY}$ & 194 & 1 & 1 & 127 & 45 & 21 \\
\hline & 3. ES & 155 & 1 & 1 & 89 & 43 & 23 \\
\hline & 4. $\mathrm{KN}$ & 113 & 6 & 3 & 61 & 29 & 13 \\
\hline & 5. SO & 212 & 47 & 17 & 115 & 18 & 16 \\
\hline \multirow[t]{3}{*}{ FH } & 1. MF & 521 & 15 & 45 & 426 & 17 & 18 \\
\hline & 2. TS & 443 & 6 & 11 & 411 & 10 & 5 \\
\hline & 3. $\mathrm{NN}$ & 415 & 8 & 9 & 365 & 22 & 12 \\
\hline \multirow[t]{2}{*}{ non FH } & 4. $\mathrm{KS}$ & 240 & 9 & 4 & 194 & & \\
\hline & 5. YK & 237 & 66 & 12 & 126 & 15 & 17 \\
\hline
\end{tabular}

間に抽出物質の濃度勾配を作製し, 下室の濃度が より高いほど, 単球が下室に向かって遊走するか 否かを検討した。

\section{III. 結 果}

\section{1. checker board assay (Table 2 )}

正常者単球を用いて, 大動脈壁抽出物質の走化 活性を検討した結果, 下室側の抽出物質濃度が大 となるにつれ, 遊走する細胞数が増加し, 一方, 上室側の濃度が大の時には, 細胞の遊走が認めら
れないことから,このような単球の運動は chemokinesis ではなく, chemotaxis であることが確認 された.

\section{2. 正常者および FH患者のリポ蛋白組成} (Tables 3, 4)

コントロール群の TC がいずれも $220 \mathrm{mg} / \mathrm{d} l$ 以 下であるのに対し, FH 患者 3 例の TC は 415 $521 \mathrm{mg} / \mathrm{d} l$ であり，特に LDL-TC は 3 例とも 400 $\mathrm{mg} / \mathrm{d} l$ 前後と著明に高值であった. non-FH 患者 2 例の TC は，正常值をわずかに超えた值であった. 
大動脈壁抽出物質に対する正常者と家族性高コレステロール血症患者の末梢血単球の遊走能

Table 4 Triglyceride concentration $(\mathrm{mg} / \mathrm{d} l)$

\begin{tabular}{rllrccccc}
\hline \multicolumn{2}{c}{ Case } & & Serum & VLDL & IDL & LDL & HDL $_{2}$ & HDL $_{3}$ \\
\hline \multirow{6}{*}{ Control } & 1. & HK & 48 & 36 & 2 & 8 & 2 & 2 \\
& 2. & KY & 41 & 16 & 1 & 13 & 7 & 4 \\
& 3. & ES & 32 & 10 & 3 & 12 & 4 & 4 \\
& 4. & KN & 66 & 45 & 5 & 10 & 5 & 1 \\
\multirow{5}{*}{ FH } & 5. & SO & 233 & 156 & 21 & 34 & 11 & 11 \\
& 1. & MF & 115 & 34 & 15 & 63 & 2 & 1 \\
& 2. & TS & 72 & 14 & 5 & 50 & 1 & 2 \\
& 3. & NN & 82 & 38 & 8 & 28 & 4 & 4 \\
non FH & 4. & KS & 76 & 51 & 4 & 17 & & 5 \\
& 5. & YK & 212 & 160 & 13 & 25 & 7 & 7 \\
\hline
\end{tabular}

Table 5 Monocyte migration by aortic extract

\begin{tabular}{|c|c|c|c|}
\hline \multirow{2}{*}{\multicolumn{2}{|c|}{ Case }} & \multirow{3}{*}{$\begin{array}{c}\text { Migrated cell number } \\
\text { by aortic extract/control } \\
158.5 / 14.0\end{array}$} & \multirow{3}{*}{$\begin{array}{c}\begin{array}{c}\text { Chemotactic index (C.I. }) \\
(\mathrm{M} \pm \mathrm{SD})\end{array} \\
11.3\end{array}$} \\
\hline & & & \\
\hline \multirow[t]{5}{*}{ Control } & 1. $\mathrm{HK}$ & & \\
\hline & 2. $\mathrm{KY}$ & $175.0 / 9.5$ & 18.4 \\
\hline & 3. ES & $49.0 / 4.0$ & 12.2 \\
\hline & 4. $\mathrm{KN}$ & $99.7 / 9.0$ & 11.1 \\
\hline & 5. SO & $56.0 / 3.5$ & $16.0(13.8 \pm 3.2)$ \\
\hline \multirow[t]{3}{*}{ FH } & 1. $\mathrm{MF}$ & $421.0 / 14.0$ & 30.1 \\
\hline & 2. TS & $312.2 / 8.8$ & 35.7 \\
\hline & 3. $\mathrm{NN}$ & $131.3 / 3.5$ & 37.5 \\
\hline \multirow[t]{2}{*}{ non FH } & 4. KS & $102.2 / 5.0$ & 20.4 \\
\hline & 5. YK & $86.0 / 4.5$ & $19.1(28.6 \pm 8.5)^{*}$ \\
\hline
\end{tabular}

*; $\mathrm{p}<0.01$ (vs. normal)

コントロール群，患者群とも第 1 例から第 4 例 までは，TG 值は $150 \mathrm{mg} / \mathrm{d} l$ 以下であるが，第 5 例は両群とも高トリグリセリド血症を示しており， VLDL-TG が高值であった.

\section{3. 正常者, FH 患者 - 単球の遊走能 (Table 5)}

正常者および FH 患者, non FH 患者の単球を 用いて, 大動脈壁抽出物質に対する走化性を比較 検討すると chemotactic index (C.I.) は，コント ロール群で $10 \sim 20(13.8 \pm 3.2 \mathrm{M} \pm \mathrm{SD})$ であるの

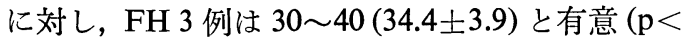
0.01) に高值を示した.

また，軽度の高コレステロール血症を呈した non FH 症例 IIa 型, IIb 型の C.I. は, 20 前後で コントロール群と $\mathrm{FH}$ 症例の中間の值を示した。 高コレステロール血症症例全体でも $28.6 \pm 8.5$ と コントロール群に比し有意 $(\mathrm{p}<0.01)$ に高值を示 した.

なお，高トリグリセリド血症を呈した 2 例につ
いては，明らかな遊走能の立進は認められなかこ た.

\section{IV. 考案}

本研究により, 大動脈壁抽出物質, すなわち組 織液および細胞内の水溶性画分には, 末梢血単球 の遊走を促進する物質が存在することが示された。 また，こうした物質が大動脈壁の肉眼的に正常と 思われる部位に存在していたことは, 動脈硬化巣 形成の初期の段階に単球 $-\mathrm{M} \phi$ の集簇が関与する 可能性を示すものと思われた。

一方，このような抽出物質に対する走化性は， FH - 単球で有意に立進していた。 Gerrity ら ${ }^{15)}$ は, 高コレステロール食で飼育した Swine において, 同様に単球の走化性が方進することを報告してお り, 高コレステロール環境下で, 単球の細胞内代 謝系路が活性化されるものと推論している.

このことは, 動脈壁の代謝異常のみならず，単 
球 - $\mathrm{M} \phi$ の易走化性が動脈硬化初期病巣の形成に 関与する可能性を示唆しており，FH の動脈硬化 易発症性において，何らかの役割りを果たしてい るものと考えられた.

本研究中の FH 3 例において, 薬剂 (Probucol, CS-514) を投与した第 1 例と第 2 例は，未治療の 第 3 例に比し，TC が高值を示していたにもかか わらず，単球の走化性，すなわち C.I. はむしろ 低值を示しており，このような薬剤の影響につい ても検討していく必要があるものと思われた.

\section{V. 結 語}

1. 末梢血単球に，大動脈壁抽出物質に対する 走化性が認められた。

2. この走化性は, FH - 単球で有意に充進し ていた

3. 以上のことより，FH の動脈硬化易発症に おいては, 単球 - $\mathrm{M} \phi$ の動脈壁内一の走化性圥進 も一因となることが考えられた。

\section{文献}

1) Deuel, T. F., Senion, R. M. and Griffin, G. L.: Chemotaxis of monocytes and neutrophils to platelet-derived growth factor. J. Clin. Invest., 69: 1046-1049 (1982).

2) Postlewaite, A. E. and Kang, A. H.: Collagen and collagen peptide induced chemotaxis of human blood monocytes. J. Exp. Med., 143: 1299-1307 (1976).

3) Hunninghake, G. W., Davidson, J. M. and Crystal, R. G.: Elastin fragments sttract macrophage precursors to diseased sites in pulmonary emphysema. Science, 212: 925-927 (1981).

4) Gallin, J. I. and Kaplan, A. P.: Mononuclear cell chemotactic activity of kallikrein and plasminogen activator and its inhibition by Clinhibitor. J. Immunol., 113: 1928-1934 (1974).

5) Norris, D. A., Clark, R. A. F. and Howell, S. E.: Fibronectin fragment(s) are chemotactic for human peripheral blood monocytes. J. Immunol., 129: 1612-1618 (1982).

6) Bar-Shavit, R., Kahn, A. and Wilper, G. D.: Chemotactic responses of monocytes to thrombin. J. Cell. Biol., 96: 282-285 (1983).

7) Janchem, J. R., Lopez, M. and Schwartz, C. J.: Mononuclear cell chemoattractant activity from cultured arterial smooth muscle cells. Exp. Mol. Pathol., 37: 166-174 (1982).

8) Sobel, J. D. and Gallin, J. I.: Polymorphonuclear leukocyte chemoattractants produced by human fibroblasts. J. Clin. Invest., 63: 609-618 (1979).

9) Berliner, J. A., Territo, M., Almada, L. and Fogelman, A. M.: Monocyte chemotactic factor produced by large vessel endotherial cells in vitro. Arteriosclerosis, 6: 254-258 (1986).

10) Mazzone, T., Jensen, M. and Chait, A.: Human arterial wall cells secrete factors that are chemotactic for monocytes. Proc. Natl. Acad. Sci. U.S.A., 80: 5094-5097 (1983).

11) Havel, R. J., Eder, H. A. and Bragdon, J. H.: The distribution and chemical composition of ultracentrifugally separated lipoproteins in human serum. J. Clin. Invest., 34: 1345-1353 (1955).

12) Boyum, A.: Isolation of mononuclear cells and granulocytes from humsn blood. Scan. J. Clin. Lab. Invest., 21: 77-89 (1968).

13) Hoff, H. F., Heideman, C. L., Ganbatz, J. W. and Jackson, R. L.: Quantification of apolipoprotein B in grossly normal human aorta. Circ. Res., 40: 56-64 (1977).

14) Horwitz, D. A. and Garett, M. A.: Quantitation of mononuclear and polymorphonuclear leukocyte chemotaxis with polycarbonate filters. J. Immunol., 106: 649-655 (1971).

15) Gerrity, R. G., Goss, J. A. and Soby, L.: Control of monocyte recruitment by chemotactic factor(s) in lesion-prone areas of swine aorta. Arteriosclerosis, 5: 55-66 (1985). 


\title{
Summary \\ Monocyte Migration Induced by Extracts of Aorta: Comparison between Normal Subjects and Familial Hypercholesterolemia
}

\author{
Hidetoshi Kotake, Shin-ichi Oikawa, Yutaka FujII, Saburo Hori, \\ Norihiro SuzUki, Kazuyuki Namai, Eriko SaKuma, Kazuko Yoshie \\ and Yoshio Goto
}

The Third Department of Internal Medicine, Tohoku University School of Medicine, Sendai

\begin{abstract}
Studies in animal models suggest that monocyte accumulation in the arterial intima is an important early event in the initiation of atherosclerosis. It has been reported that chemotactic factors for monocytes can be extracted from vessels of cholesterol fed animals. The present study indicated that extracts from intima and media of normal portion of human thoracic aorta induced monocytes chemotaxis. Checker board analysis showed that the activity was due to chemotaxis and not to chemokinesis. We investigated the chemotactic activity of aortic extracts for monocytes from
\end{abstract}

normal subjects and familial hypercholesterolemia $(\mathrm{FH})$. The data indicated that chemotactic index (C.I.) in FH was 2-3 times greater than that in normal subjects.

These findings indicated that there were monocyte-chemotactic factors in the intima and media of normal aorta and that control of monocyte recruitment into artery would involve not only alteration of the arterial wall but also functional changes in the circulating monocytes.

Key words: Monocyte, migration, aortic extract. 